\title{
Comparison study of lead-acid and lithium-ion batteries for solar photovoltaic applications
}

\section{B. V. Rajanna, Malligunta Kiran Kumar}

Department of Electrical and Electronics Engineering, Koneru Lakshmaiah Education Foundation, Vaddeswaram, Guntur-522502, Andhra Pradesh, India

\section{Article Info}

\section{Article history:}

Received Feb 1, 2021

Revised Mar 5, 2021

Accepted Mar 13, 2021

\section{Keywords:}

Battery energy storage system Discharge-charge Lead-acid battery Lithium-ion battery Solar pv utility grid system

\begin{abstract}
The battery energy storage systems are very essential for maintaining constant power supply when using solar photovoltaic systems for power generation. The viability and ability of battery energy storage systems are assessed based on battery usage in Solar Photovoltaic utility grid-connected systems. The power supply quality and reliability are improved by utilizing battery energy storage technologies in conjunction with solar photovoltaic systems. This paper presents a comparative analysis of Lead-Acid Storage battery and Lithium-ion battery banks connected to a utility grid. The battery mathematical model simulation study gives their performance characteristics of these batteries under grid-connected loads. Cost-benefit analysis of battery usage for determining the best battery suitable for solar photovoltaic system applications is also presented in this paper.
\end{abstract}

This is an open access article under the CC BY-SA license.

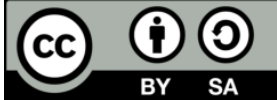

\section{Corresponding Author:}

B. V. Rajanna

Department of Electrical and Electronics Engineering

Koneru Lakshmaiah Education Foundation

Vaddeswaram, Guntur-522502, Andhra Pradesh, India

Email: bv.rajanna@gmail.com

\section{NOMENCLATURE}

$I_{p v}$

$V_{p v}$

$I_{s c}$

$I_{0}$

$N_{s}$

$N_{p}$

$\mathrm{T}$

$\mathrm{B}_{\mathrm{c}}$

Q

$R_{S}$

$R_{p}$

$Q_{d}$

E

$I_{b a t}$

$V_{\text {bat }}$

$R_{\text {bat }}$
SOC

$\mathrm{E}_{\mathrm{o}}$

K

$\mathrm{Q}_{\max }$

$\mathrm{Q}$

Current in PV cell (A)

Voltage in PV cell (V)

Short-circuit current of the PV cell (A)

Current at Saturation level (A)

Number of Series connected PV cells

Number of Parallel connected PV cells

p-n junction temperature

Boltzmann Constant

Charge of an Electron

PV Array Series Equivalent Resistance $(\Omega)$

PV Array Parallel Equivalent Resistance $(\Omega)$

Ideality Factor of Diode

Voltage Controlled Source (V)

Battery Discharge Current (A)

Battery Terminal Voltage (V)

Battery Variable Internal Resistance $(\Omega)$

Battery State of Charge (\%)

Constant battery voltage $(\mathrm{V})$

The resistance of Polarization $(\Omega)$

The capacity of Battery (Ah)

Charge in the real battery (Ah)

The magnitude of the Exponential zone (V)

The inverse time constant of Exponential zone (Ah)-1 


$\begin{array}{ll}\mathrm{i}^{*} & \text { Filtered current (A) } \\ \text { Cost } / k W & \text { Battery Cost in USD } \\ M C & \text { Maintenance Cost } \\ D O D & \text { Depth of Discharge (\%) } \\ C_{L} & \text { Cycle Life (Cycles) } \\ B_{L} & \text { Battery Life (Years) } \\ \eta & \text { Battery Efficiency }(\%)\end{array}$

\section{INTRODUCTION}

The battery energy storage system used in standalone photovoltaic systems has greatly increased in recent years [1]. Battery energy storage systems are used to augment the power supply or act as a backup power supply when the primary source fails. The power delivered by the storage system should be of the same quality and sustain the load for a predetermined duration of time. Typical Battery energy storage systems consist of a battery bank and a control circuit to manage the power delivery to the load [2]. The power management may involve feedback loops to maintain constant current or voltage and also monitor and throttle the battery temperature [3].

The core part of the battery management system is the type of battery used. The characteristics of the battery will determine the type of controls needed to operate the storage system [4]. In this paper, we consider using two types of batteries namely lead-acid and lithium-1on batteries. In most of the literature available experiments have been done to analyze the discharge characteristics of batteries [5]-[15]. In this paper, the charging characteristics of the batteries are also taken into account along with the cost-benefit analysis. The paper is organized in the following manner. The description of the utility grid-connected PV Array is discussed in Section 2. The battery's description is given briefly in Section 3. The proposed equivalent circuit model for battery types with mathematical equations are discussed in Section 4. The simulation scenarios and results are discussed in Section 5. The cost comparison of batteries are given in Section 6. The conclusion made finally given in Section 7.

\section{DETAILED DESCRIPTION OF $100 \mathrm{KW}$ UTILITY GRID CONNECTED PV ARRAY}

Power delivered by 100-kW PV array is channeled through a DC-DC boost converter which is connected to a three-phase three-level Voltage Source Converter (VSC). A three-phase three-level VSC feeds into a coupling transformer used to deliver power to a $25 \mathrm{kV}$ grid. The algorithm employed in maximum power point tracking (MPPT) is 'incremental conductance + integral regulator' [16].

The components contained in the detailed model [17], [18] are:

a. PV Array: Maximum power delivered by PV array is $100 \mathrm{~kW}$ at $1000 \mathrm{~W} / \mathrm{m}^{2}$ solar irradiance.

b. DC-DC boost converter: At maximum power, $\mathrm{PV}$ output voltage is $273 \mathrm{~V} \mathrm{DC}$ which is increased to 500

V DC by DC-DC boost converter of 5-kHz. The optimization of the switching duty cycle is done by an MPPT controller by using the 'Incremental Conductance + Integral Regulator' algorithm. The duty cycle is automatically varied by the MPPT system to provide the voltage required to take out maximum power.

c. Three-level Three-phase VSC: The output voltage of the boost converter is converted from $500 \mathrm{~V}$ DC to $260 \mathrm{~V}$ AC by $1980-\mathrm{Hz}$ Three-level Three-phase VSC and thus power factor of unity is maintained. The external control loop and internal control loops are the two control loops employed in the VSC control system [19] . Voltage regulation of DC link for $+/-250 \mathrm{~V}$ is made with external loop control and Id and Iq grid currents regulation are made with internal loop control. The output DC voltage of the external controller is given by reference current Id. The power factor of unity is maintained by setting reference current Iq to zero. PWM Generator uses three modulating signals Uabc_ref generated from current controller output voltages $\mathrm{Vd}$ and Vq. The voltage controllers, current controllers, and unit of PLL Synchronization use sample time of 100 microseconds generated by the control system. Waveforms of PWM get a suitable resolution by setting a quick sample time of 1 microsecond for Boost and VSC converters Pulse generators.

Capacitor bank: VSC harmonics are filtered by setting capacitor bank value to 10-kvar. Three-phase coupling transformer: Three-phase coupling transfer of rating $100-\mathrm{kVA} 260 \mathrm{~V} / 25 \mathrm{kV}$ is used for stepping up the VSC output voltage of $260 \mathrm{~V}$ AC to $25 \mathrm{kV}$ AC. Utility grid: The utility grid consists of a $25-\mathrm{kV}$ distribution feeder+120 kV equivalent transmission system. 330 Sun Power modules (SPR-305E-WHT-D) are used in the $100-\mathrm{kW}$ PV array. 5 modules are connected in series making a string, such 66 strings are connected in parallel. The solar cell equivalent circuit is shown in Figure 1. Solar cell characteristics are given by (1) [18]. 


$$
I_{p v}=N_{p} I_{s c}-N_{s} I_{0}\left\{e^{\left(\frac{q\left(v_{p v}+I_{p v} R_{s}\right)}{N_{s} Q_{d} B_{c} T}\right)}-1\right\}-V_{p v}+\left(\frac{I_{p v} R_{s}}{R_{p}}\right)
$$

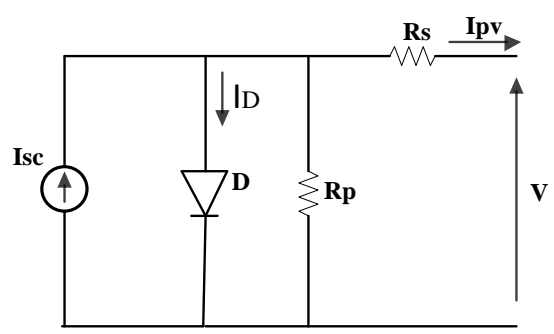

Figure 1. Solar cell equivalent circuit with Rs and Rf [18]

The dc-bus link voltage is stepped up by a dc-dc boost converter which is connected to PV Array. Boost converter suitable switching regulates the voltage of PV for maximum average PV array power output. PV Array operational voltage at a given irradiation condition varies with the PV power flow. By using the DC link in between, the Inverter and boost converter is connected. One module specifications given by the manufacturer are:

a. The number of series-connected PV cells is 96 per module.

b. The open-circuit voltage of the cell is $\mathrm{Voc}=64.2 \mathrm{~V}$

c. Short-circuit current of the cell is Isc $=5.96 \mathrm{~A}$

d. The voltage at maximum power is $\mathrm{Vmp}=54.7 \mathrm{~V}$

e. Current at maximum power is $\operatorname{Imp}=5.58 \mathrm{~A}$

f. $\quad$ Power per module $=54.7 \times 5.58=305.2 \mathrm{~W}$

Which gives a total output power of PV Array $=$ number of strings in parallel $\times$ number of modules per string $\times$ power per module $=66 \times 5 \times 305.2 \mathrm{~W}=100.7 \mathrm{~kW}$ approximately.

The solar irradiance $\left(\mathrm{W} / \mathrm{m}^{2}\right)$ and temperature (deg. C) are the two inputs given to the block of PV Array. The block of the signal builder is used to set the input values for PV Array solar irradiance and temperature.

\section{CHARACTERISTICS OF BATTERY}

One or more electrochemical cells that are connected externally to deliver power to electrical devices form a rechargeable battery. In Electrochemical cells, energy is stored in a chemical form which gives energy in an electrical form on connecting load to it. A battery which is the rechargeable battery has the following:

a. The current is entered into a polarized electrical device by the acceptance of electrons at the positive electrode (cathode). The reduction process is involved here.

b. The current leaves the polarized electrical device by the generation of electrons at the negative electrode (anode). The oxidation process is involved here.

c. The electron's electrical conduction between anode and cathode is done by the substance called electrolyte.

The energy in chemical form is converted into electrical form during the battery discharge process. The electrolyte is generally split into movable ions due to the oxidation and reduction of the negative and positive electrode. The external circuit connected to the battery receives energy from those electrons. The energy in electrical form is converted into chemical form during the charging process of the battery. The external power source supplies energy to the cell.

The battery generates current by the electrons transfer occurs between the electrodes. The potential difference between the anode and cathode gives the battery an open circuit voltage $E_{o}$, when an external load is not connected to the battery. The open-circuit voltage is generally a function of SOC i.e. $E_{o}(\mathrm{SOC})$. The state of charge (SOC) and capacity (Q) of the battery also affects the performance of the battery.

\subsection{Li-ion battery}

The active components involved in a lithium-ion battery are a negative electrode (cathode) having oxide of the lithiated metal and copper current collector, a positive electrode (anode) having layer structure graphitic carbon and aluminum current collector, electrolyte solution LIPF 6 -EC-DMC (lithium hexafluoro 
phosphate-ethylene carbonate-dimethyl carbonate) which is an electronic insulator and good ionic conductor. Polyethylene Separator is used to prevent contact between the electrodes. The operation of Lithium-Ion battery and its charging and discharging chemical reactions can be found in [20].

\subsection{Lead-acid storage battery}

The active components involved in lead-acid storage battery are negative electrode made of spongy lead $(\mathrm{Pb})$, positive electrode made of lead dioxide $\left(\mathrm{PbO}_{2}\right)$, electrolyte solution of sulphuric acid $\left(\mathrm{H}_{2} \mathrm{SO}_{4}\right)$ and Separator which is used to prevent ionic flow between electrodes and increasing of internal resistance in a cell. Operation of Lead-Acid Storage battery and its charging and discharging chemical reactions can be found in [21], [22].

\section{BATTERY MODEL}

A generic battery model from MATLAB SimPower systems library [23]-[49] with appropriate parameters is used for analyzing battery charging and discharging characteristics performance.

$$
\mathrm{V}_{\mathrm{bat}}=\mathrm{E}-\mathrm{R}_{\mathrm{bat}} \mathrm{I}_{\mathrm{bat}}
$$

The battery open circuit voltage is a function of the state of charge (SOC) [50].

The maximum battery energy extracted is represented by $Q$ in (3) [51].

$$
\mathrm{Q}=\int \mathrm{I}_{\mathrm{bat}} \mathrm{dt}
$$

Battery SOC is given in (4).

$$
\mathrm{SOC}=100 *\left(1-\frac{\mathrm{Q}}{\mathrm{Q}_{\max }}\right)
$$

Table 1. Discharge and Charge equations for Lithium-Ion battery and Lead-Acid Storage battery

\begin{tabular}{ccc}
\hline Lithium-ion Battery & Discharge & $V_{b a t}=E_{0}-R i_{\text {bat }}-K \frac{Q_{\max }}{Q_{\max }-Q}\left(Q+i^{*}\right)+A \exp (-B Q)$ \\
& Charge & $V_{\text {bat }}=E_{0}-R i_{\text {bat }}-K \frac{Q_{\max }}{Q-0.1 Q_{\max }} i^{*}-K \frac{Q_{\max }}{Q_{\max }-Q}+A \exp (-B Q)$ \\
\hline Lead-Acid Storage Battery & Discharge & $V_{b a t}=E_{0}-R i_{\text {bat }}-K \frac{Q_{\max }}{Q_{\max }-Q}\left(Q+i^{*}\right)+V \exp (t)$ \\
& Charge & $V_{b a t}=E_{0}-R i_{b a t}-K \frac{Q_{\max }}{Q-0.1 Q_{\max }} i^{*}-K \frac{Q_{\max }}{Q_{\max }-Q}+V \exp (t)$ \\
\hline
\end{tabular}

\subsection{Lithium-Ion battery}

The discharge controlled voltage is given in [52]. It solves the problem caused due to the algebraic loop during the system simulation in Matlab/Simulink. The resistance of polarization during discharge for all kinds of battery is similarly given in [53]. During the charging process, the voltage of the battery is increased due to the absorption of too much energy on the system. The resistance of polarization during charge is given in,

$$
\begin{aligned}
& \mathrm{E}=\mathrm{E}_{0}-\mathrm{K} \frac{\mathrm{Q}_{\max }}{\mathrm{Q}_{\max }-\mathrm{Q}} \mathrm{Q}-\mathrm{K} \frac{\mathrm{Q}_{\max }}{|\mathrm{Q}|-0.1 \mathrm{Q}_{\max }} \mathrm{i}^{*}+\mathrm{Ae}^{-B \mathrm{Q}} \\
& \mathrm{R}_{\text {pol }}=\mathrm{K} \frac{\mathrm{Q}_{\max }}{\mathrm{Q}_{\max }-\mathrm{Q}} \\
& \mathrm{R}_{\text {pol }}=\mathrm{K} \frac{\mathrm{Q}_{\max }}{\mathrm{Q}-0.1 \mathrm{Q}_{\max }}
\end{aligned}
$$

\subsection{Lead-acid storage battery}

Exponential voltage includes a hysteresis phenomenon between battery charge-discharge given by (8)-(10), [54], [55]. $\mathrm{i}(\mathrm{t})$ sign is given by $\mathrm{u}(\mathrm{t})$. During the discharge process, $\mathrm{u}(\mathrm{t})=0$ and during the charging process $\mathrm{u}(\mathrm{t})=1$. So, the discharge controlled voltage is given in,

$$
\dot{\mathrm{V}}_{\exp }(\mathrm{t})=\mathrm{B}|\mathrm{i}(\mathrm{t})|\left(-\mathrm{V}_{\exp }(\mathrm{t})+\mathrm{Au}(\mathrm{t})\right)
$$




$$
\mathrm{E}=\mathrm{E}_{0}-\mathrm{K} \frac{\mathrm{Q}_{\max }}{\mathrm{Q}_{\max }-\mathrm{Q}} \mathrm{Q}-\mathrm{K} \frac{\mathrm{Q}_{\max }}{|\mathrm{Q}|-0.1 \mathrm{Q}_{\max }} \mathrm{i}^{*}+\mathrm{E}_{\exp }(\mathrm{t})
$$

The lead-acid storage battery voltage decreases slowly due to the full charging of the battery based on the magnitude of the current. The end of charge is not the same for this battery like other batteries. Overcharging the battery decreases the battery voltage slowly [19]. The resistance of polarization given in :

$$
\mathrm{R}_{\mathrm{pol}}=\mathrm{K} \frac{\mathrm{Q}_{\max }}{|\mathrm{Q}|-0.1 \mathrm{Q}_{\max }}
$$

\subsection{Equivalent model summary} in Table. 1.

Discharge and Charge equations for Lithium-Ion battery and Lead-Acid Storage battery are shown

\section{SIMULATION SCENARIOS AND RESULTS}

Two battery types Lead-Acid Storage Battery and Lithium-Ion Battery having a rating of $582.5 \mathrm{~V}$ at $100 \%$ SOC and 100 Ah Capacity are used. Two simulation scenarios have been carried out to understand the discharging and charging performance of the batteries. The proposed system block diagram for simulation as shown in Figure 2.

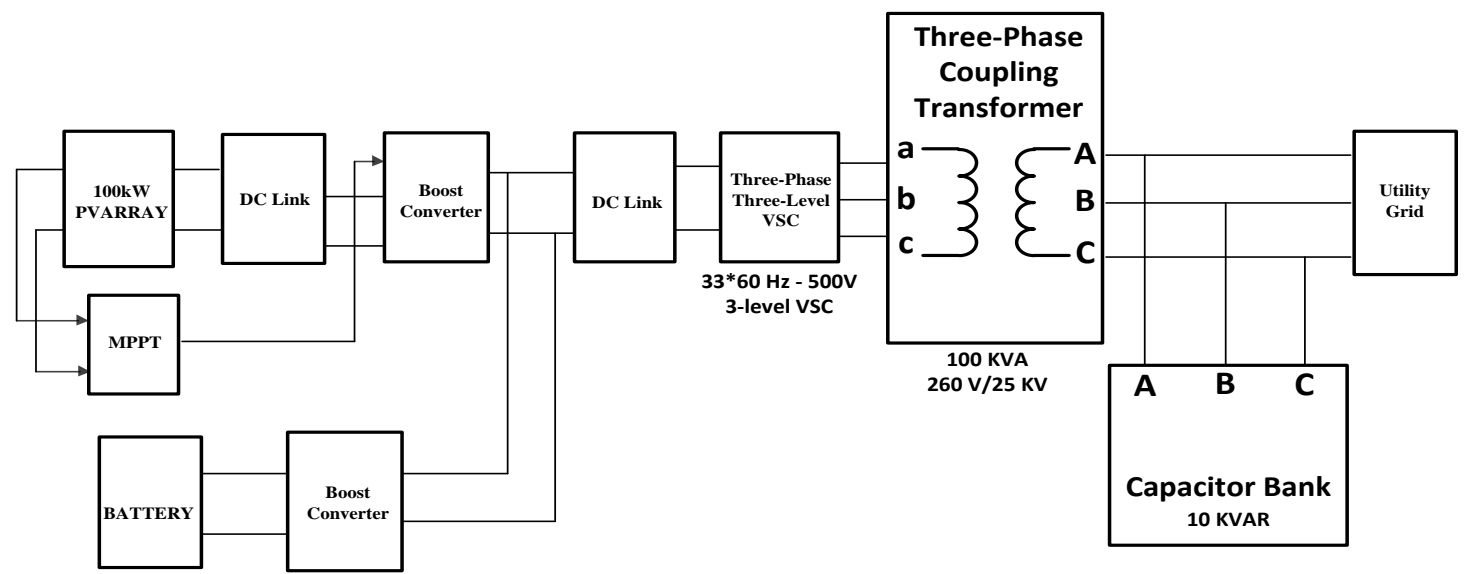

Figure 2. Proposed system block diagram for simulation

Scenario 1: Boost Converter and VSC Converter will not get any pulses from $\mathrm{t}=0 \mathrm{sec}$ to $\mathrm{t}=0.05$ sec. DC link capacitors are charged by boosting the PV voltage above $500 \mathrm{~V}$. Voltage across DC link capacitors is used to drive the voltage source inverter which acts as a three-phase rectifier. Boost and VSC circuits get activated at $\mathrm{t}=0.05 \mathrm{sec}$. The voltage of $\mathrm{Vdc}=500 \mathrm{~V}$ at the $\mathrm{DC}$ link is maintained. The duty cycle applied to boost converter is 0.5 .

Initially, at $\mathrm{t}=0.05 \mathrm{sec}$, only PV Array alone is catering to the power demand of the utility grid. When Solar irradiance falls from $1000 \mathrm{~W} / \mathrm{m}^{2}$ to $250 \mathrm{~W} / \mathrm{m}^{2}$ at $\mathrm{t}=1 \mathrm{sec}$ as shown in Figure 3, the PV Array is unable to support the power demand alone, now power from the battery energy storage bank is drawn to compensate for the shortage of the power delivered by the PV Array.

At $\mathrm{t}=1.2 \mathrm{sec}$, the Steady-state is reached. Output power of PV Array at $\mathrm{t}=0.05 \mathrm{sec}+$ is Pmean $=96$ $\mathrm{kW}$. MPPT is enabled at $\mathrm{t}=0.4 \mathrm{sec}$. The MPPT regulator starts regulating PV voltage by varying the duty cycle to extract maximum power. From $\mathrm{t}=1 \mathrm{sec}$ to $\mathrm{t}=12 \mathrm{sec}$ batteries start delivering power to the utility grid. The discharging performance comparison of two batteries such as Lithium-ion and Lead-Acid Storage battery is carried out. The input values are given to the PV Array by the signal builder block. The PV Array Irradiance Ir, Temperature, Mean Power (Pmean) and Mean Voltage (Vmean); Duty Cycle of Boost Converter is shown in Figure 3. 


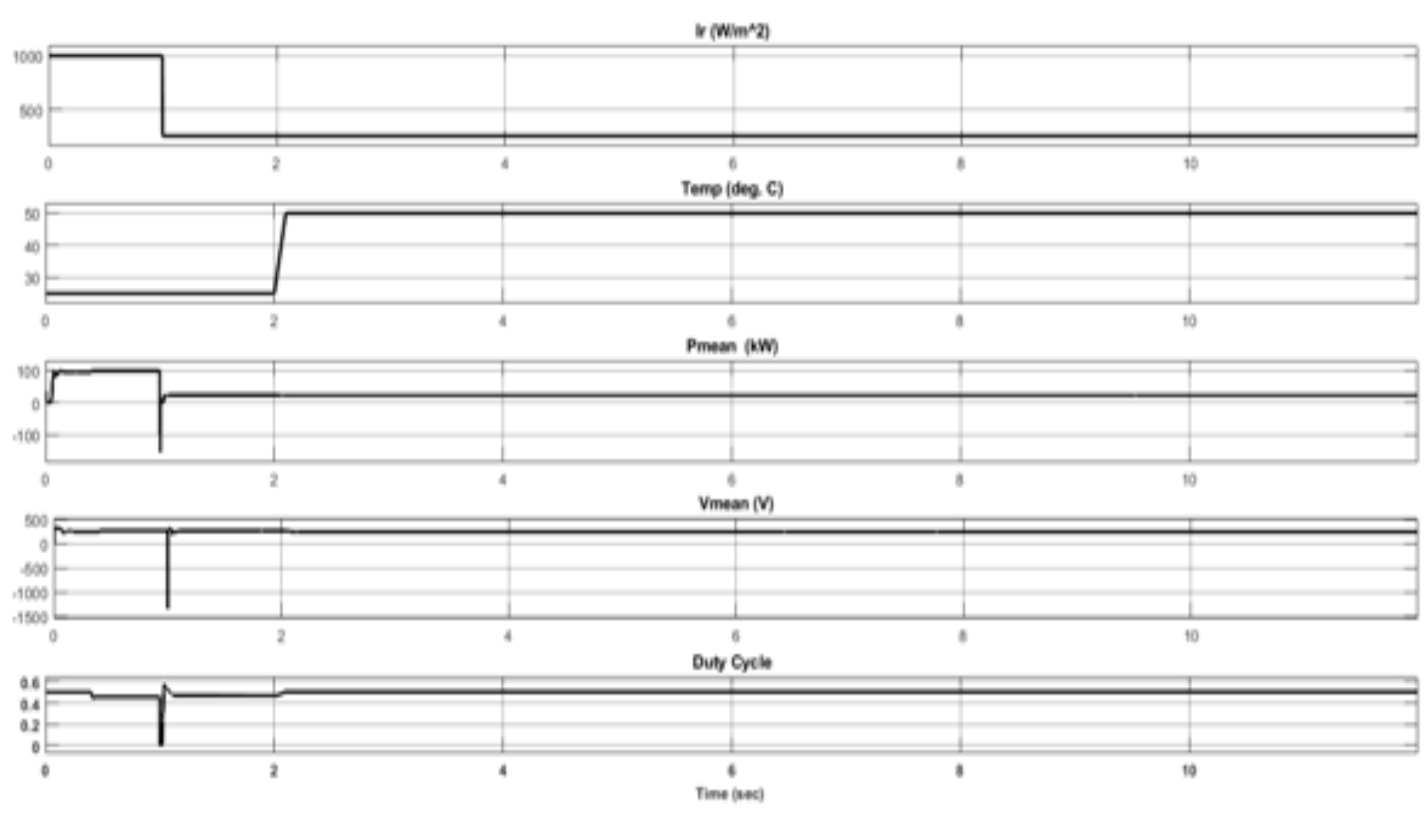

Figure 3. PV array irradiance ir, temperature, mean power (pmean) and mean voltage (vmean); duty cycle of boost converter

The batteries discharging voltage comparisons at different percentages of SOCs are shown in the above Figure 4. The batteries charging voltage comparison at $20 \%$ SOC, batteries charging current is the same, batteries SOCs comparison at $20 \%$ SOC and utility grid power comparison at $20 \%$ SOC of batteries are shown in Figure 11. The power supplied by the battery bank at different percentages of SOCs is shown in the Figure 7.
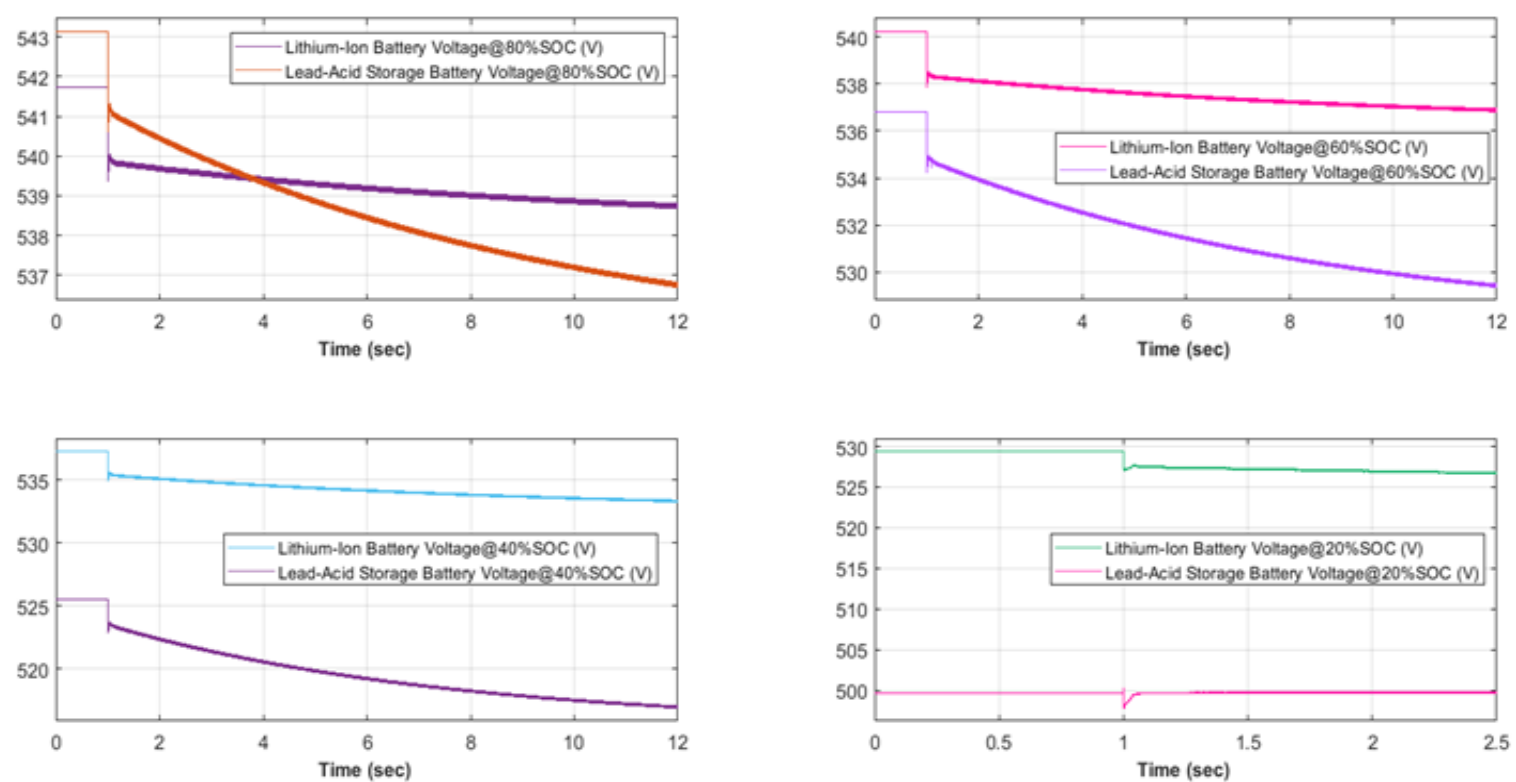

Figure 4. Batteries discharging voltage comparison at different percentages of SOCs batteries discharging voltage comparison at different percentages of SOCs 
Table 2. Battery discharging voltage, discharging current and SOC comparison at various percentages of SOCs

\begin{tabular}{|c|c|c|c|c|c|c|c|c|c|c|c|c|}
\hline \multirow[t]{2}{*}{$\begin{array}{l}\text { Battery } \\
\text { Type }\end{array}$} & \multicolumn{8}{|c|}{$\begin{array}{l}\text { Scenario } 1 \\
\text { Battery Discharging Current } \\
\text { at various } \% \text { of SOCs (A) }\end{array}$} & \multicolumn{4}{|c|}{ Battery SOC (\%) } \\
\hline & 80 & 60 & 40 & $\begin{array}{c}20 @ 2 . \\
5 \mathrm{sec}\end{array}$ & 80 & 60 & 40 & 20 & 80 & 60 & 40 & $\begin{array}{r}20 @ 2 . \\
5 \mathrm{sec}\end{array}$ \\
\hline $\begin{array}{c}\text { Lithium-Ion } \\
\text { Battery }\end{array}$ & $\begin{array}{c}538.7 \\
8\end{array}$ & $\begin{array}{c}536 . \\
9\end{array}$ & $\begin{array}{c}533 . \\
4\end{array}$ & 526.7 & 36.1 & 35.7 & 34.8 & $\begin{array}{c}35 . \\
8\end{array}$ & $\begin{array}{c}79.8 \\
87\end{array}$ & $\begin{array}{c}59.8 \\
87\end{array}$ & $\begin{array}{c}39.8 \\
89\end{array}$ & $\begin{array}{c}19.984 \\
5\end{array}$ \\
\hline $\begin{array}{l}\text { Lead-Acid } \\
\text { Storage } \\
\text { Battery }\end{array}$ & $\begin{array}{c}536.7 \\
9\end{array}$ & $\begin{array}{c}529 . \\
5\end{array}$ & 517 & 499.8 & 33.2 & 31.4 & 26.5 & 0 & $\begin{array}{c}79.8 \\
96\end{array}$ & $\begin{array}{c}59.8 \\
99\end{array}$ & $\begin{array}{c}39.9 \\
08\end{array}$ & 20 \\
\hline
\end{tabular}

Table 3. Power supplied by battery bank and utility grid power comparison at various percentages of SOCs

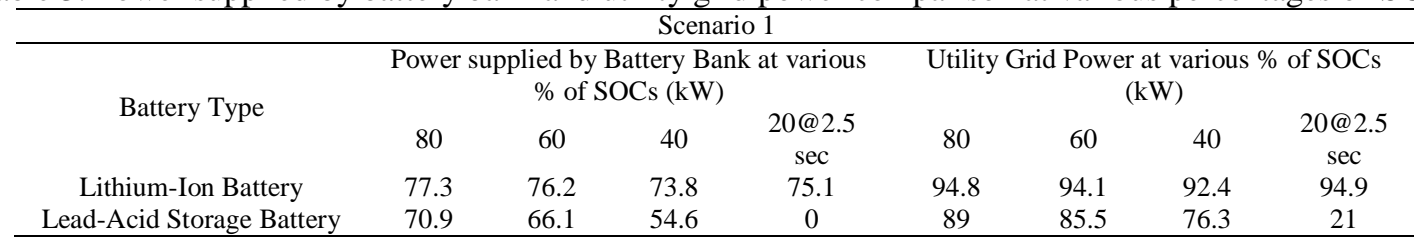

Table 4. Battery charging voltage, charging current and SOC comparison at various percentages of SOCs

\begin{tabular}{ccccccc}
\hline \multicolumn{9}{c}{ Scenario 2 } \\
\hline Battery Type & $\begin{array}{c}\text { Battery Charging Voltage at } \\
\text { various \% of SOCs (V) }\end{array}$ & $\begin{array}{c}\text { Battery Charging Current } \\
\text { at various \% of SOCs (A) }\end{array}$ & Battery SOC (\%) \\
& 20 & 79 & 20 & 79 & 20 & 79 \\
Lithium-Ion Battery & 531 & 544.1 & 23.6 & 23 & 20.0365 & 79.077 \\
Lead-Acid Storage Battery & 513.4 & 567.4 & 24.5 & 21.9 & 20.0372 & 79.071 \\
\hline
\end{tabular}

The battery performances characteristics are shown in graphs for exact values at points of interest are given in Tables 2, 3, 4, and 5. Throughout the discharging time as observed in our simulation study [ref Figure 9], Lithium-Ion battery has delivered the higher power to the utility grid. Further, when we continue to discharge the battery banks, on reaching 20\% SOC, the Lead-Acid Storage Battery Bank fails to deliver any power as the battery bank's current falls to zero [ref Figure 5]. The Lithium-Ion battery bank continues to deliver substantial power to the utility grid. This shows that Lithium-Ion batteries are capable of deep discharge i.e. Lithium-ion batteries have a higher depth of discharge and higher specific energy when compared to Lead-Acid Storage batteries.
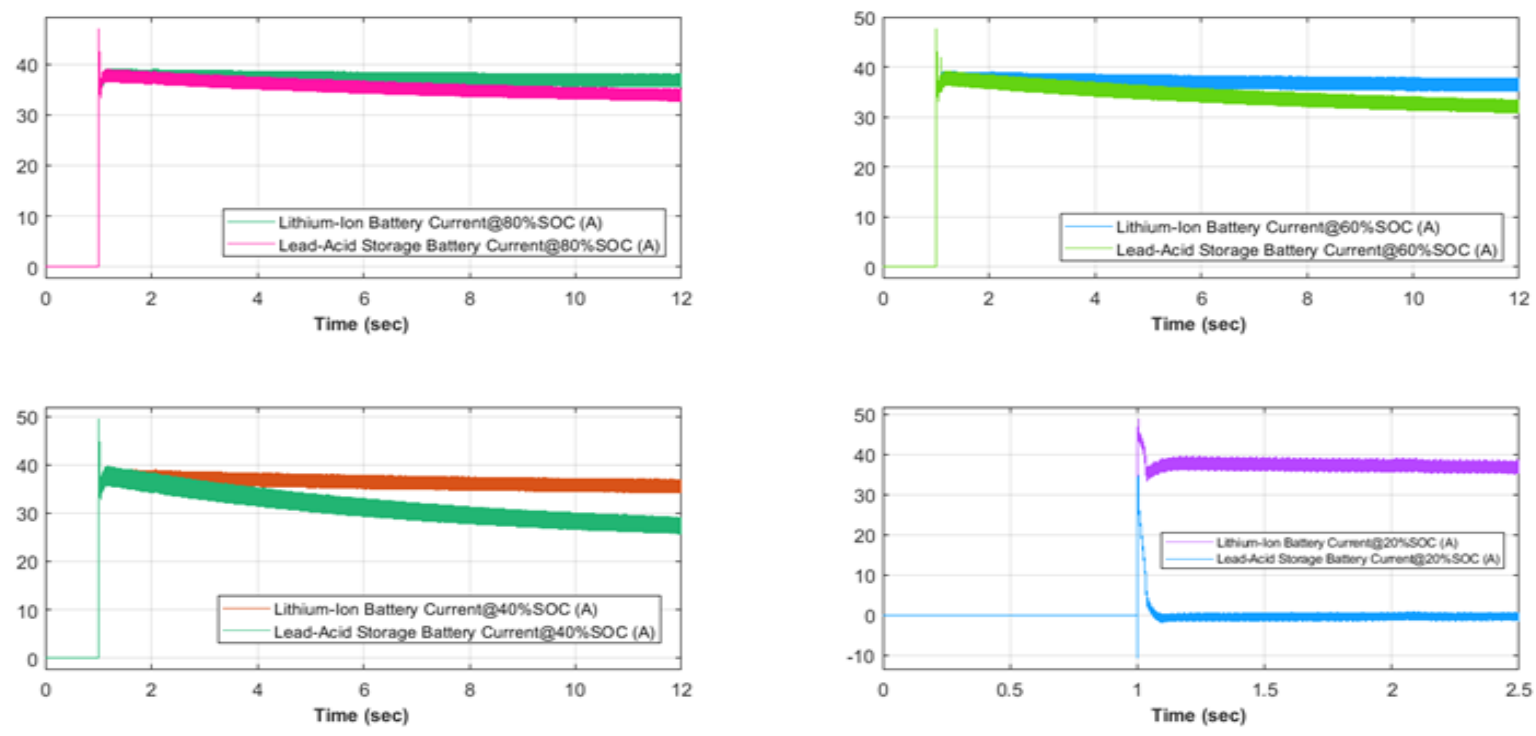

Figure 5. Batteries discharging current comparison at different percentages of SOCs the batteries discharging current comparison at different \% of SOCs are shown in above Figure 5.

Comparison study of lead-acid and lithium-ion batteries for solar photovoltaic applications (B V Rajanna) 
Even though the SOCs of Lithium-Ion and Lead-Acid batteries do not differ much while charging [ref Figure 11]. Batteries Comparison at different percentages of SOCs The batteries comparison at a different percentage of SOCs is shown in the Figure 6, utility grid voltage va and ia the utility grid voltage is maintained at $20 \mathrm{kV}$ for batteries at different SOCs and Grid Current is approximately $3.5 \mathrm{~A}$ is shown in Figure 8.
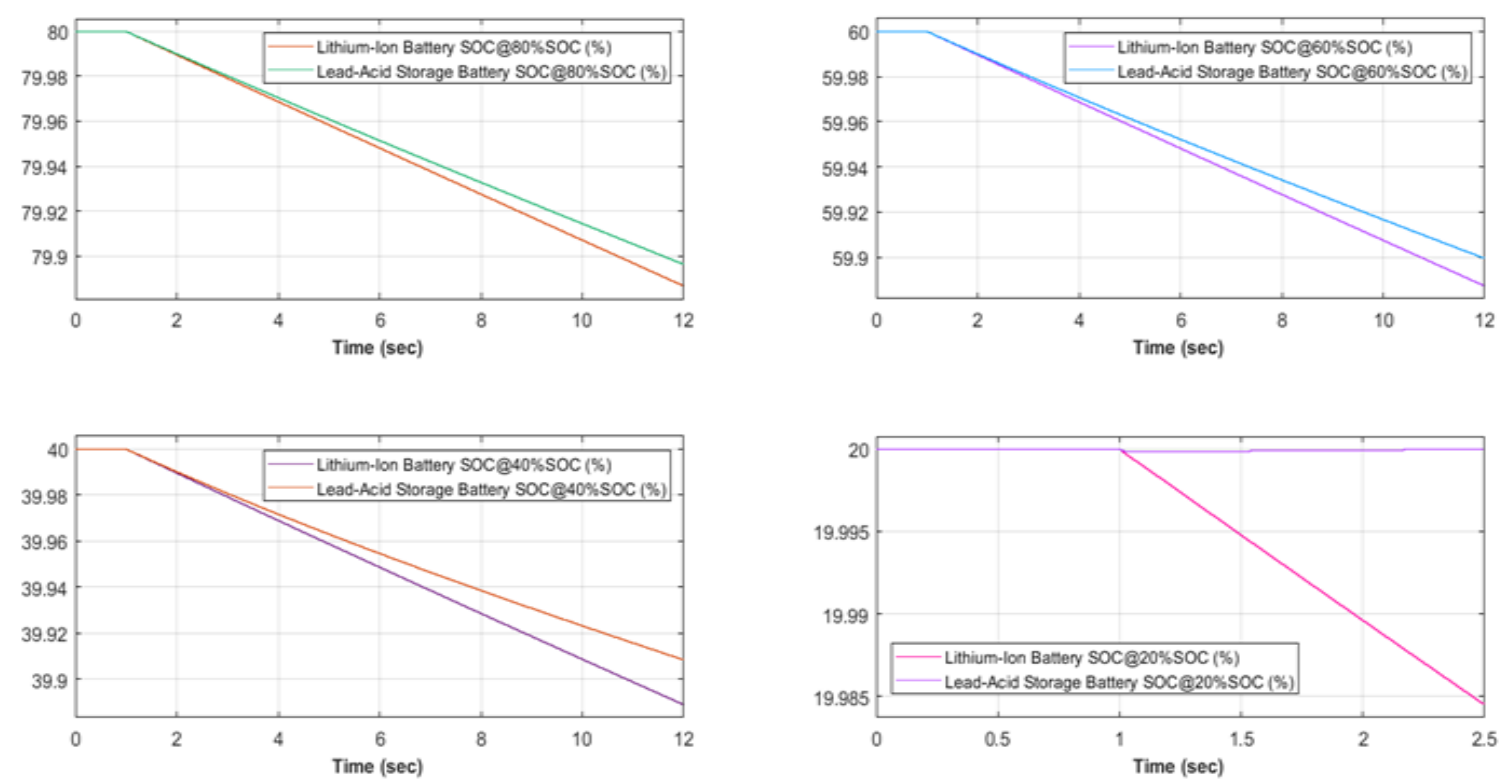

Figure 6. Batteries comparison at different percentages of SOCs the batteries comparison at a different percentage of SOCs is shown in the above Figure 6.
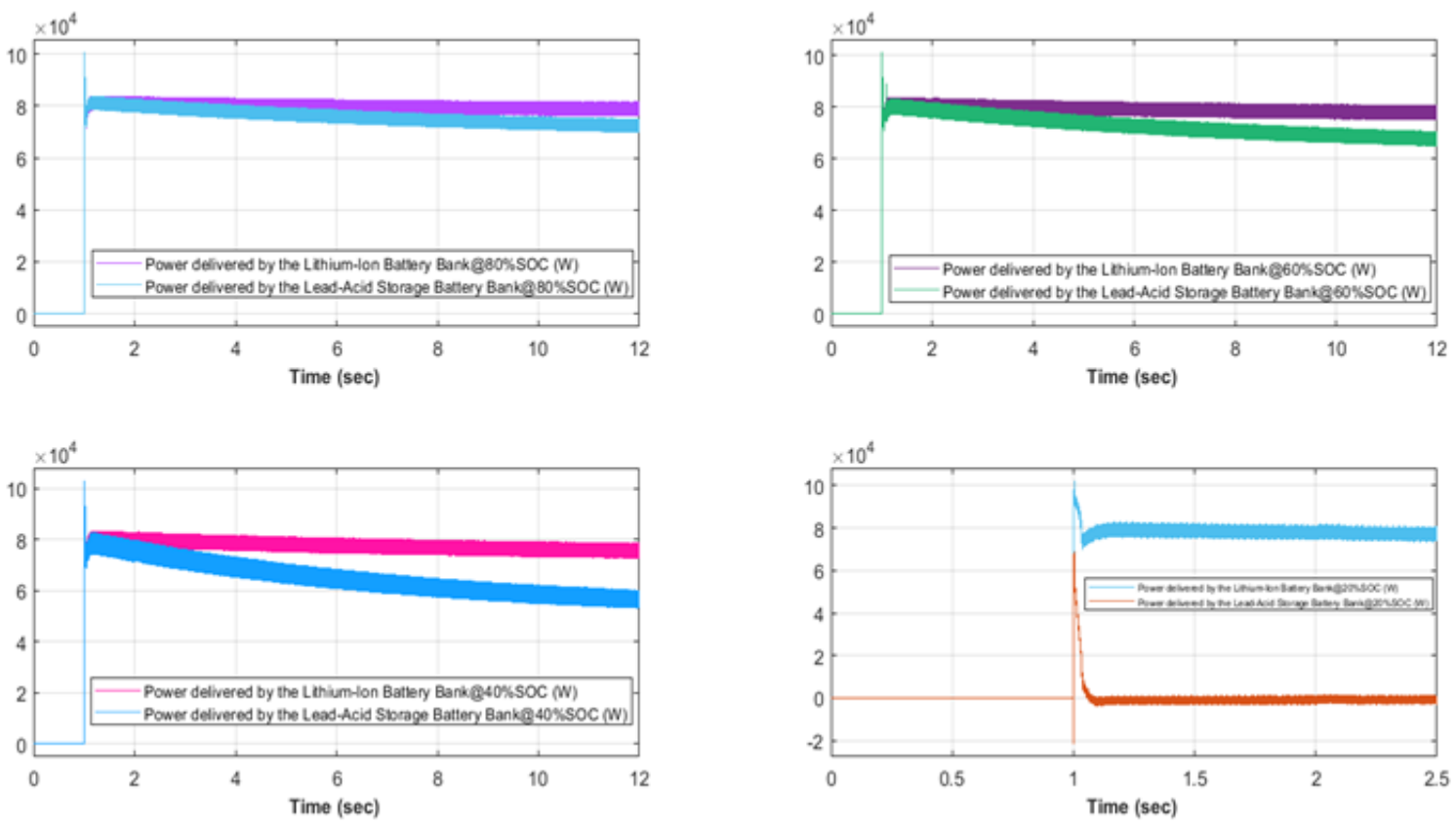

Figure 7. Power supplied by battery bank at different percentages of SOCs Power supplied by Battery Bank at different percentages of SOCs is shown in Figure 7

It is also noticed from behavior that Lithium-Ion Battery bank having the same rated capacity delivered higher power [ref Figure 9], which means that the Specific Power of the Lithium-Ion battery bank 
is greater than Lead-Acid Storage battery. Because of high specific power, Lithium-Ion battery can be used for applications like power tools and energy storage banks in hybrid utility grids, where there is higher power demand in a short duration of time.
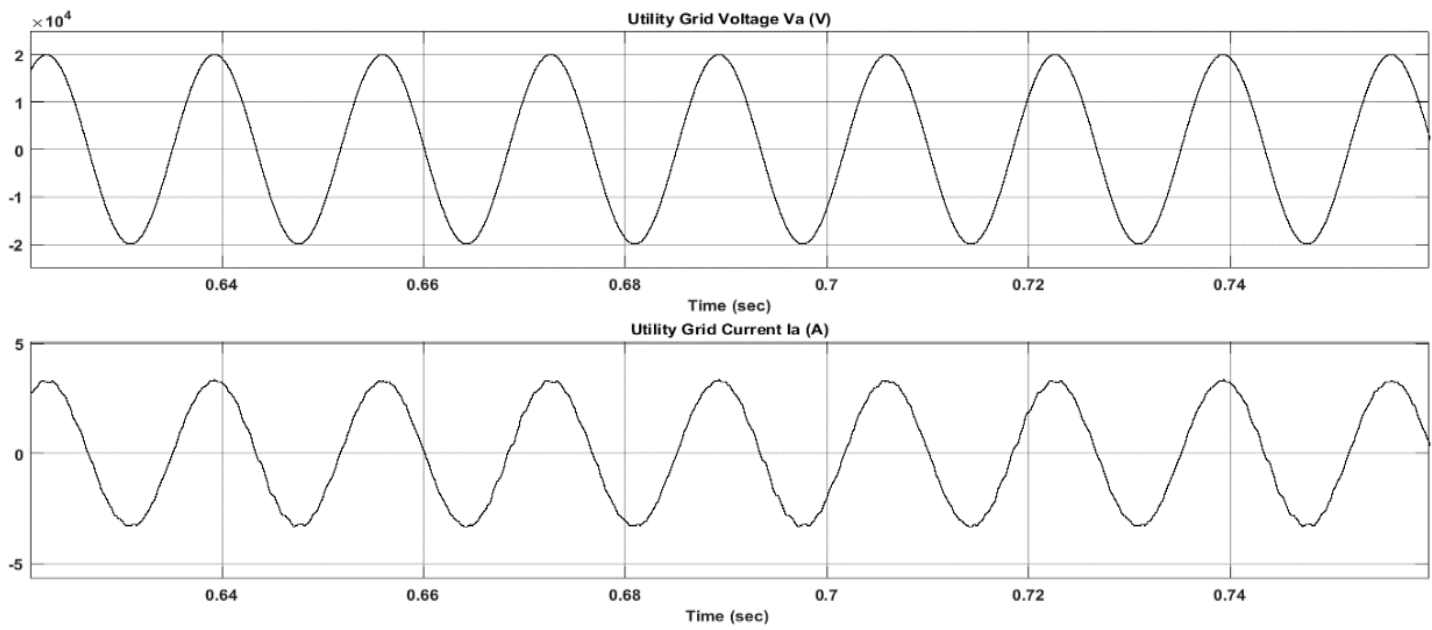

Figure 8. Utility grid voltage $\mathrm{Va}$ and Ia the utility grid voltage is maintained at $20 \mathrm{kV}$ for batteries at different SOCs and Grid Current is approximately $3.5 \mathrm{~A}$ is shown in Figure 8.
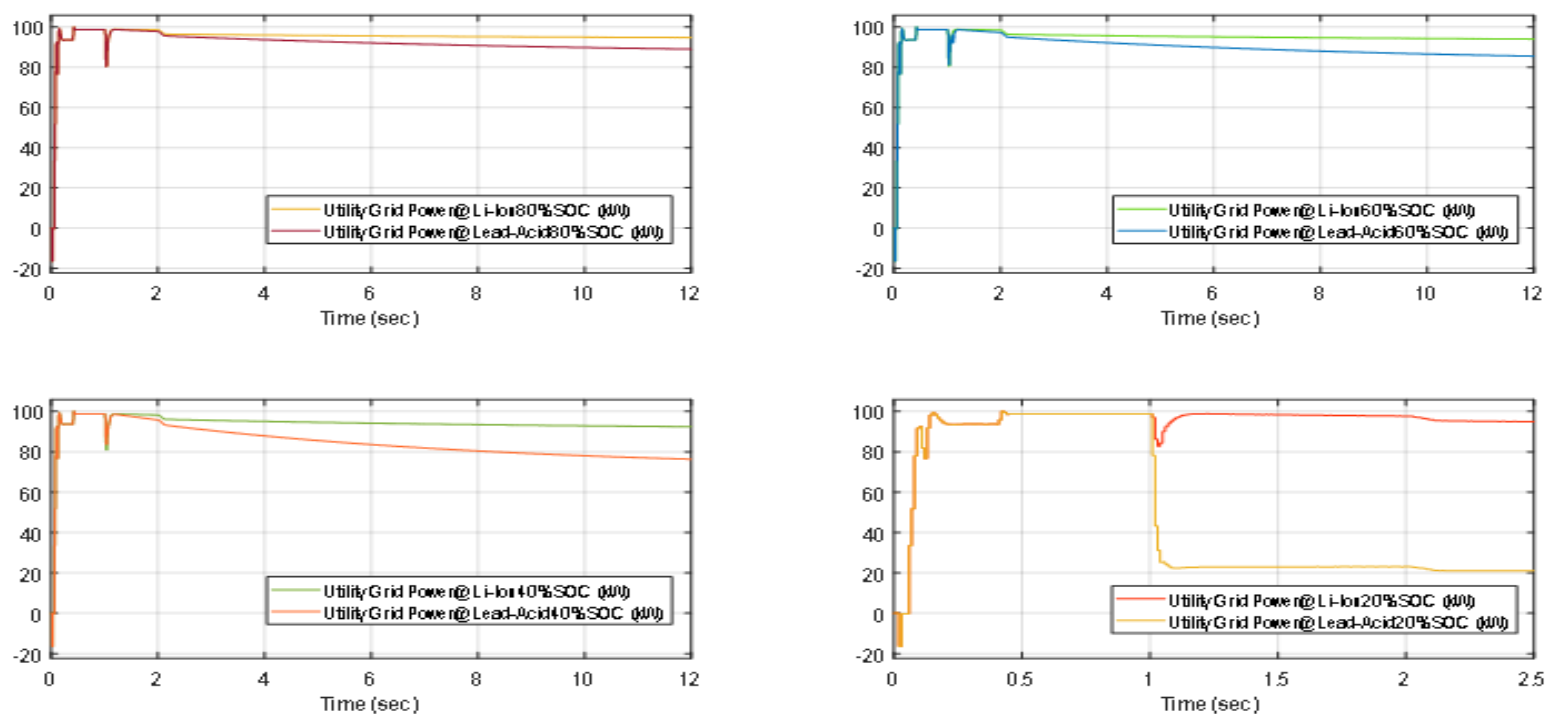

Figure 9. Utility grid power comparison at different percentages of SOCs of Batteries

Scenario 2: Initially at $\mathrm{t}=0 \mathrm{sec}, \mathrm{PV}$ Array alone is catering to utility grid power demand. When Solar irradiance increases from $1000 \mathrm{~W} / \mathrm{m} 2$ to $1600 \mathrm{~W} / \mathrm{m} 2$ at $\mathrm{t}=1 \mathrm{sec}$ as shown in Figure 10 , the excess power generated by the PV array is used to charge the battery bank. The input values are given to the PV Array by the signal builder block. The battery banks are charged while maintaining constant power output to the utility grid. The voltage controller circuit comprises of boost converter connected to input terminals of the battery bank. PWM controller is used for generating gating signals for IGBT Switch. By varying the duty cycle of the IGBT Switch, the charging voltage is controlled. Charging performance comparison of two battery types Lithium-ion and Lead-Acid Storage battery is carried out.

At close to $80 \%$ SOC, Lead-Acid Storage Battery terminal voltage increases rapidly. Because of this maintaining the same rate of charge as earlier will require more power in case of the constant charging voltage, the lead-acid storage battery will take more time to charge as the charging current decreases as can be inferred from Figure 12. 


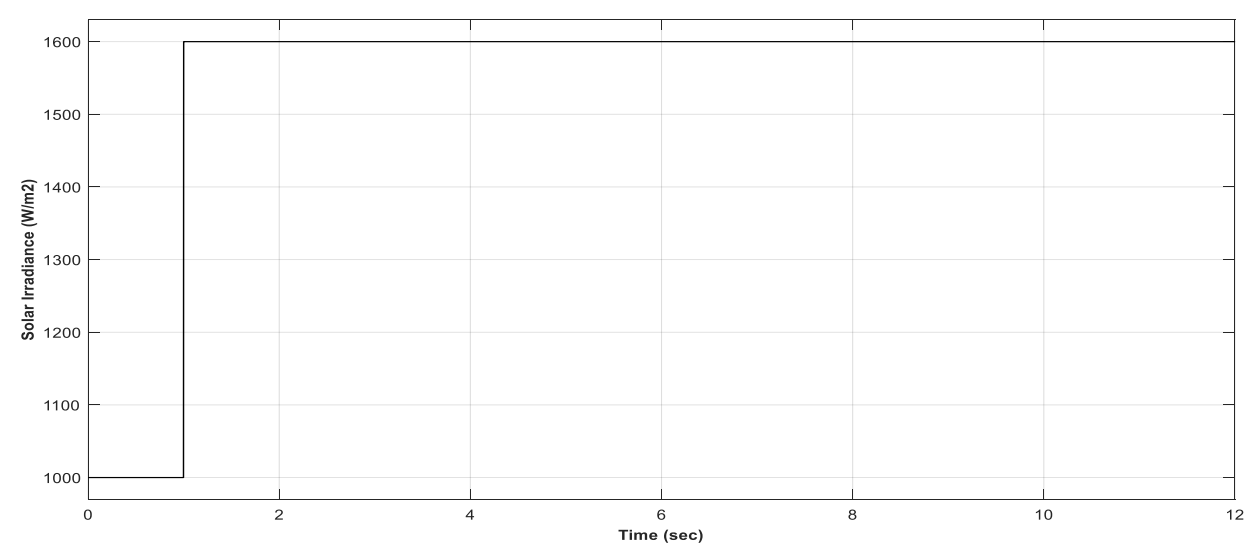

Figure 10. Step up Solar Irradiance
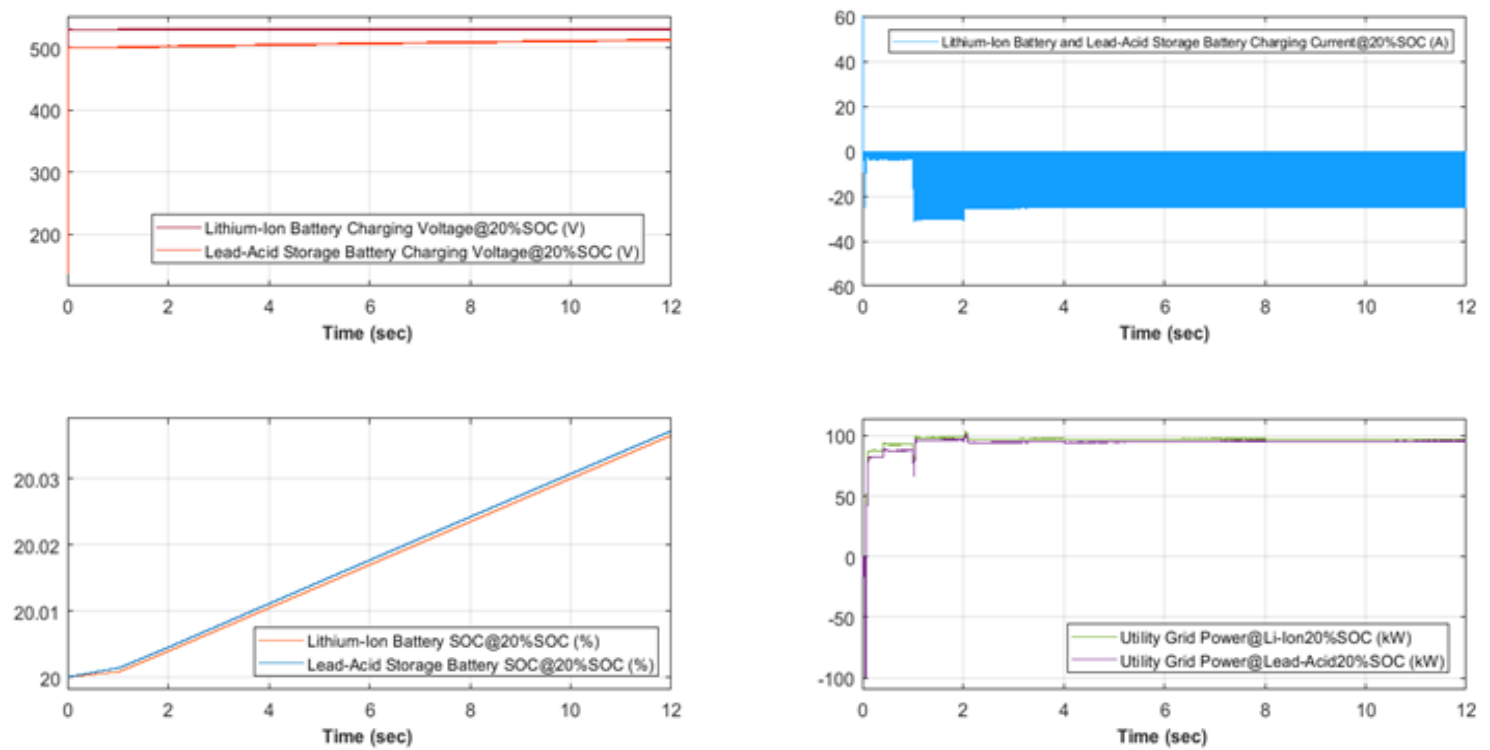

Figure 11. Batteries charging voltage comparison, batteries charging current, batteries SOCs comparison, and utility grid power at $20 \%$ SOCs of batteries

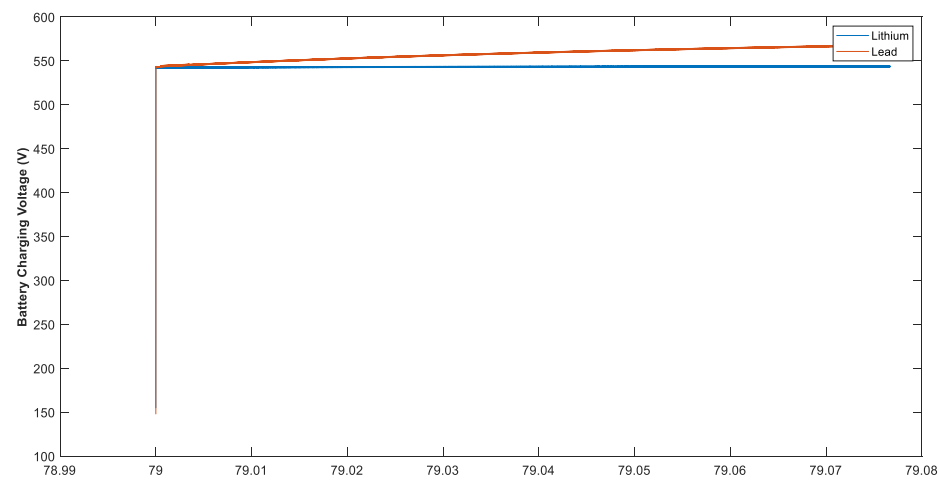

Figure 12. Batteries charging voltage vs. SOC comparison 


\section{COST COMPARISON OF LEAD-ACID AND LITHIUM-ION BATTERIES}

When comparing the cost of different types of batteries, it is important to consider various parameters and their effects on costs. Each of these parameters for different batteries has different values and because of this, it is difficult to conclude by comparing these values directly. For example, the price of a Lithium-Ion battery is very high when compared to a lead-acid storage battery but the maintenance cost of the Lithium-Ion battery is very low. This may translate into a lower overall cost of Lithium-Ion battery in the long run.

One way to address the above issue is to come up with a heuristic metric by taking the required battery parameters into account. As use case is storage battery for PV grids, it is to come up with a heuristic while taking the following parameters into account. These are Battery Cost in USD, Maintenance cost, Depth of Discharge, Cycle Life, Battery Life, and Battery Efficiency. Note: Gravimetric energy density is not considered because it is not an important factor for static battery applications. Based on the relation between various parameters, we have arrived at metric given by expression Based on the above heuristic, Lead-Acid Battery is 2.79 times costlier than Lithium-Ion Battery. The values used for the computation of said heuristic metric are shown in Table 5. All the values are estimates based on market values.

$$
\text { Average Cost } / \mathrm{kW}=\frac{\operatorname{Cost} / \mathrm{kW} \cdot \mathrm{E}_{\mathrm{D}} \cdot \mathrm{MC}}{\mathrm{DOD} \cdot \mathrm{C}_{\mathrm{L}} \cdot \mathrm{B}_{\mathrm{L}} \cdot \eta}
$$

Table 5. Performance parameters

\begin{tabular}{lll}
\hline Parameter & Lithium-Ion Battery & Lead-Acid Storage Battery \\
\hline Volumetric energy density (Wh/L) & $250-360$ & $54-95$ \\
Gravimetric energy density (Wh/kg) & $110-175$ & $30-40$ \\
Depth of discharge (DOD) & $80 \%$ & $50 \%$ \\
Cycle life & $1900-3000 @ 80 \%$ DOD & $500-1000 @ 50 \%$ DOD \\
Recycling cost & High & Low \\
Efficiency & $97 \%$ & $75 \%$ \\
Life time (year) & 12 & 10 \\
Cost $/ \mathrm{kW}$ & $150 \mathrm{USD}$ & $100 \mathrm{USD}$ \\
Maintenance costs/kW & $0.04-3.1$ & $0.03-6.6$ \\
Average cost/kW & 5.9922 & 16.72 \\
\hline
\end{tabular}

\section{CONCLUSION}

The following conclusions can be derived from the results obtained from section 5 and 6 . A comparative analysis of two types of batteries is presented in this paper. Results show that Lithium-Ion battery has better discharging voltage, discharging current than Lead-Acid Storage battery at various percentages of state of charge. It is also observed that while maintaining constant load voltage, Lithium-Ion battery delivers more power to utility grid. Lead-Acid battery consumes more power when charged to $100 \%$ state of charge. Lead-Acid Storage Battery is 2.79 times costlier than Lithium-Ion Battery. So, for a solar photovoltaic system with high power demand, a Lithium-Ion battery is more suitable both performance-wise and cost-wise.

\section{REFERENCES}

[1] Olivier Tremblay and Louis-A. Dessaint, "Experimental Validation of a Battery Dynamic Model for EVApplications," World Electric Vehicle Journal, Vol. 3, no. 2, pp. 289-298, June 2009, DOI: 10.3390/wevj3020289.

[2] D. Linden, T. B. Reddy, "Lead Acid Batteries," Handbook of Batteries, 3rd ed. New York, NY: McGraw-Hill, 2002.

[3] Chemical Kinetics (3rd Edition) 3rd Edition by Keith J. Laidler (Author), Pearson India; 2003.

[4] Chemical Kinetics and Reaction Dynamics by Paul L. Houston, Dover Publications, 2006.

[5] J. Appelbaum and R. Weiss, "An Electrical Model of the Lead-Acid Battery," INTELEC '82-International Telecommunications Energy Conference, Washington, DC, USA, pp. 304-307, 1982, DOI: 10.1109/INTLEC.1982.4793747.

[6] Z. Salameh, M. Casacca, and W. A. Lynch, "A mathematical model for Lead-acid batteries," in IEEE Transactions on Energy Conversion, vol. 7, pp. 93-98, Mar 1992, DOI: 10.1109/60.124547.

[7] M. Casacca and Z. Salameh, "Determination of lead-acid battery capacity via mathematical modeling techniques," in IEEE Transactions on Energy Conversion, vol. 7, pp. 442-446, Sep 1992, DOI: 10.1109/60.148564.

[8] R. Rynkiewicz, "Discharge and charge modeling of lead-acid batteries," Applied Power Electronics Conference and Exposition, 1999. APEC'99. Fourteenth Annual, vol. 2, pp. 707-710, IEEE, 1999, DOI: 10.1109/APEC.1999.750438. 
[9] Ceraolo, "New Dynamical Models of Lead-Acid Batteries," in IEEE Transactions on Power Systems, vol. 15, no. 4, IEEE, November 2000, DOI: 10.1109/59.898088.

[10] S. Barsali and M. Ceraolo, "Dynamical models of lead-acid batteries: implementation issues," in IEEE Transactions on Energy Conversion, vol. 17, pp. 16-23, Mar 2002, DOI: 10.1109/60.986432.

[11] Cai Chenghui, Du Dong, Ge Jingtian, Liu Zhiyu, and Zhang Hua, "Battery-charging model to study transient dynamics of battery at high frequency," TENCON '02. Proceedings. IEEE Region 10 Conference on Computers, Communications, Control, and Power Engineering, vol. 3, pp.1843-1846, 2002, DOI: 10.1109/TENCON.2002.1182695.

[12] H. Khafagy and A. Makki, "Mathematical modeling and simulation of lead-acid battery," on Proceedings 2004 International Conference Information and Communication Technologies: From Theory to Applications, pp. 137, April 2004, DOI: 10.1109/ICTTA.2004.1307653.

[13] Jossen, "Fundamentals of battery dynamics," in J. Power Sources, vol. 154, no. 2, pp. 530-538, 2006, DOI: 10.1016/j.jpowsour.2005.10.041.

[14] M. Chen and G. A. Rincon-Mora, "Accurate electrical battery model capable of predicting runtime and I-V performance," in IEEE Transactions on Energy Conversion, vol. 21, no. 2, pp. 504-511, 2006, DOI: 10.1109/TEC.2006.874229.

[15] Jackey, R, "A Simple, Effective Lead-Acid Battery Modeling Process for Electrical System Component Selection," SAE Technical Paper, 2007, DOI: 10.4271/2007-01-0778.

[16] Moacyr A. G. de Brito, Leonardo P. Sampaio, Luigi G. Jr., Guilherme A. e Melo, Carlos A. Canesin, "Comparative Analysis of MPPT Techniques for PV Applications", 2011 International Conference on Clean Electrical Power (ICCEP), 2011, DOI: 10.1109/ICCEP.2011.6036361.

[17] Muni T. V, Lalitha S. V. N. L, "Power management strategy in a solar PV system with battery protection scheme in dc microgrid," in International Journal of Innovative Technology and Exploring Engineering, vol. 8, no. 6, pp. 960-964, 2019, DOI: 10.5013/ijssst.a.20.01.37.

[18] B. V Rajanna, S. V. N. L Lalitha, Ganta Joga Rao, and S K Shrivastava, "Solar photovoltaic generators with MPPT and battery storage in microgrids," in International Journal of Power Electronics and Drive Systems (IJPEDS), vol. 7, no. 3, pp. 701-712, Sep 2016, DOI: 10.11591/ijpeds.v7.i3.pp701-712.

[19] B. Srikanth Goud, B Loveswara rao, and Ch Rami Reddy, "Essentials for Grid Integration of Hybrid Renewable Energy Systems: A Brief Review," in International Journal of Renewable Energy Research, vol. 10, no. 2, pp. 813830, 2020.

[20] B V Rajanna and Malligunta Kiran Kumar, "Comparison of one and two time constant models for lithium-ion battery," in International Journal of Electrical and Computer Engineering (IJECE), vol. 10, no. 1, pp. 670-680, Feb 2020, DOI: 10.11591/ijece.v10i1.pp670-680.

[21] Peng, Wenxin, "Accurate circuit model for predicting the performance of lead-acid AGM batteries," UNLV Theses, 2011.Dissertations, Professional Papers, and Capstones, p. 1244, http://dx.doi.org/10.34917/2821019.

[22] B V Rajanna and Malligunta Kiran Kumar, "Dynamic model development for a lead-acid storage battery," in Indonesian Journal of Electrical Engineering and Computer Science (IJEECS), vol. 15, no. 2, pp. 609-619, Aug 2019, DOI: 10.11591/ijeecs.v15.i2.pp609-619.

[23] O. Tremblay, Louis-A. Dessaint, and A. Dekkiche "A Generic Battery Model for the Dynamic Simulation of Hybrid Electric Vehicles," IEEE Vehicle Power and Propulsion Conference, pp. 284-289, 2007, DOI: 10.1109/VPPC.2007.4544139.

[24] Guru Prasad S, Srikanth K.S, Rajanna B.V, "Advanced active power filter performance for grid integrated hybrid renewable power generation systems," in Indonesian Journal of Electrical Engineering and Computer Science (IJEECS), vol. 11, no. 1, pp. 60-73, 2018, DOI: 10.11591/ijeecs.v11.i1.pp60-73.

[25] B. Schweighofer, M. Recheis, T. Gallien, and H.Wegleiter, "Fast and accurate battery model including temperature dependency," Industrial Electronics Society, IECON 2013-39th Annual Conference of the IEEE, pp. 6740-6745, Nov 2013, DOI: 10.1109/IECON.2013.6700248.

[26] L. C. Stevanatto, V. J. Brusamarello, and S. Tairov, "Parameter Identification and Analysis of Uncertainties in Measurements of Lead-Acid Batteries," in IEEE Transactions on Instrumentation and Measurement, vol. 63, no. 4, pp. 761-768, April 2014, DOI: 10.1109/TIM.2013.2283545.

[27] N. Kularatna, "Dynamics and Modeling of Rechargeable Batteries: What electrochemists? Work tells the electronic engineers," in IEEE Power Electronics Magazine, vol. 1, no. 4, pp. 23-33, Dec. 2014, DOI: 10.1109/MPEL.2014.2361264.

[28] Ramesh V and Latha Y. K, "Performance improvement of grid-connected PV system using new converter topologies," Proceedings of the 2017 2nd IEEE International Conference on Electrical, Computer and Communication Technologies, Coimbatore, India, 22-24 Feb. 2017, ICECCT 2017, DOI: 10.1109/ICECCT.2017.8118002.

[29] Donepudi S. R, Priyanka M. V, Jahnavi K, Swathi M, "Optimization of an energy storage device in the photovoltaic system," in International Journal of Applied Engineering Research, vol. 12, special no.1, pp. 547-552, 2017.

[30] Srikanth M, Vijay Muni T, VishnuVardhan M, Somesh D, "Design and simulation of PV-wind hybrid energy system," in Journal of Advanced Research in Dynamical and Control Systems, vol. 10, no. 4, pp. 999-1005, 2018.

[31] K. C. Divya, J. Østergaard, "Battery Energy Storage Technology for power systems-An overview," in Electric Power Systems Research, pp. 511-520, 2009, DOI: 10.1016/j.epsr.2008.09.017. 
[32] Poullikkas, "A comparative overview of large-scale battery systems for electricity storage," in Renewable and Sustainable Energy Reviews, pp.778-788, 2013, DOI: 10.1016/j.rser.2013.07.017.

[33] M. G. Molina and P. E. Mercado, "Modeling and control of grid-connected photovoltaic energy conversion system Used as a dispersed generator," in Proc. 2008 IEEE/PES Transm. Distrib. Conf. Expo.: Latin America, pp. 1-8, 2008, DOI: 10.1109/TDC-LA.2008.4641871.

[34] M. G. Villalva, J. R. Gazoli, and E. R. Filho, "Comprehensive approach to modeling and simulation of photovoltaic Arrays," in IEEE Trans. Power Electron., vol. 24, no. 5, pp. 1198-1208, 2009, DOI: 10.1109/TPEL.2009.2013862.

[35] Joseph and Med. Shahidehpour, "Battery Storage System in electric power systems," IEEE, 2006, DOI: 10.1109/PES.2006.1709235.

[36] Low Wen Yao, Aziz, J. A., Pui Yee Kong, N. R. N. Idris "Modeling of Lithium-Ion Battery Using MATLAB/Simulink," IEEE, 2013, DOI: 10.1109/IECON.2013.6699393.

[37] Chao Lu, Hanchen Xu, Xin Pan, and Jie Song, "Optimal Sizing and Control of Battery Energy Storage System for Peak Load Shaving," in Energies, pp. 8396-8410, 2014, DOI: 10.3390/en7128396.

[38] Kumar B. P, Srikanth M, "Photovoltaic-Standalone system with SMES-battery energy storage system cascaded MLI for rural area applications," in International Journal of Recent Technology and Engineering, vol. 7, no. 6, pp. 2064-2068, 2019.

[39] Kumaraswamy G, Srinivasa Varma P, and Chandrasekhar P, "Grid interconnected multi-level inverter-based PV system," in Journal of Advanced Research in Dynamical and Control Systems, vol. 9, special no. 18, pp. 154-160, 2017.

[40] X. Luo, J. Wang, M. Dooner, and J. Clarke, "Overview of current development in electrical energy storage technologies and the application potential in power system operation," in Applied Energy, pp. 511-536, 2015, DOI: 10.1016/j.apenergy.2014.09.081.

[41] S. Li, B. Ke, "Study of Battery Modeling using Mathematical and Circuit Oriented Approaches," IEEE, 2011, DOI: 10.1109/PES.2011.6039230.

[42] J. Cho, S. Jeong, Y. Kim, "Commercial and research battery technologies for electrical energy storage applications," in Progress in Energy and Combustion Science, pp. 84-101, 2015, DOI: 10.1016/j.pecs.2015.01.002.

[43] Darabi, M. Hosseina, H. Gholami, M. Khakzad, "Modeling and Simulation of Lead- Acid Storage Batteries within Photovoltaic Power Systems," in International Journal of Emerging Technology and Advanced Engineering, pp.2250-2459, 2013.

[44] D. Guasch, S. Silvestre "Dynamic battery model for photovoltaic applications," in progress in photovoltaics: research and applications, pp. 193-206, 2003, DOI: 10.1002/pip.480.

[45] M. Chen and G. A. Rincon-Mora, "Accurate electrical battery model capable of predicting runtime and i-v performance," in IEEE transactions on energy conversion, vol. 21, no. 2, pp. 504-511, 2006, DOI: 10.1109/TEC.2006.874229.

[46] E. M. G. Rodrigues, R. Godina, G. J. Osório, J. M. Lujano-Rojas, J. C.O. Matias, and J. P. S. Catalão, "Comparison of battery models for energy storage applications on insular grids," 2015 Australasian Universities Power Engineering Conference (AUPEC), Wollongong, NSW, pp. 1-6, 2015, DOI: 10.1109/AUPEC.2015.7324861.

[47] N. Akbar, M. Islam, S. S. Ahmed, and A. A. Hye, "Dynamic model of battery charging," TENCON 2015-2015 IEEE Region 10 Conference, Macao, pp. 1-4, 2015, DOI: 10.1109/TENCON.2015.7372996.

[48] C. Cedric, S. Adnan, A. D. Ahmed, and S. M. Muyeen, "Modeling and analysis of battery performance for renewable energy application," 2013 15th European Conference on Power Electronics and Applications (EPE), Lille, pp.110, 2013, DOI: 10.1109/EPE.2013.6634462.

[49] R. Sparacino, G. F. Reed, R. J. Kerestes, B. M. Grainger, and Z. T.Smith, "Survey of battery energy storage systems and modeling techniques," 2012 IEEE Power and Energy Society General Meeting, SanDiego, CA, pp.1-8, 2012, DOI: 10.1109/PESGM.2012.6345071.

[50] Suraj G. O, Narasimha Raju K, Trivedi N, "Comparative analysis of Li-Ion battery charging with different rectifier topologies," in International Journal of Innovative Technology and Exploring Engineering, vol. 8, no. 5, pp. 420424, 2019.

[51] Ravi Kumar K. S, Mohanta D. K, Sastry V.V, Rajesh D, Sekhar O. C, and Varma M. P. C, "Design and fabrication of coulomb counter for estimation of SOC of battery," IEEE International Conference on Power Electronics, Drives and Energy Systems, PEDES 2016, pp. 1-6, 2017, DOI: 10.1109/PEDES.2016.7914473.

[52] Vijay Muni T, Lalitha S. V. N. L, Rajasekhar Reddy B, Shiva Prasad T, and Sai Mahesh K, "Power management system in PV systems with dual battery," in International Journal of Applied Engineering Research, vol. 12, special no. 1, pp. 523-529, 2017.

[53] Mamatha G, Rangasai D, Avinash S, and Naveen M, "Integration of solar PV with the grid," in International Journal of Applied Engineering Research, vol. 12, special no. 1, pp. 430-434, 2017.

[54] Vijay Muni T, Srikanth K. S, Venkatesh N, Sumedha K. L, "A high-performance hybrid MPPT control scheme for a grid-connected PV system based three-level NPCMLI," in International Journal of Engineering and Technology(UAE), vol. 7, no. 2, pp. 37-40, 2018, DOI: 10.14419/ijet.v7i2.20.11741.

[55] Vijay Muni T and Lalitha S. V. N. L, "Implementation of control strategies for optimum utilization of solar photovoltaic system with energy storage systems," in International Journal of Renewable Energy Research, vol. 10, no. 2, pp. 716-726, 2020. 


\section{BIOGRAPHIES OF AUTHORS}
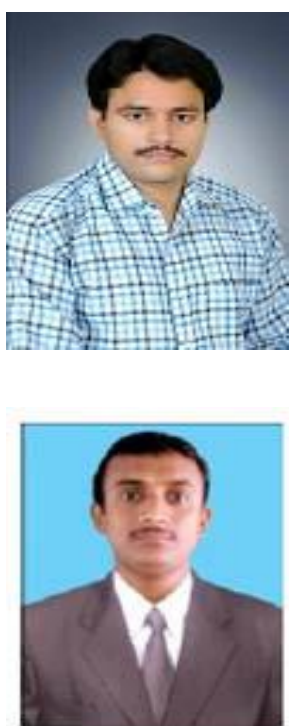

B V Rajanna received B.Tech degree in Electrical and Electronics Engineering from Chirala Engineering College, JNTU, Kakinada, India, in 2010, M.Tech degree in Power Electronics and Drives from Koneru Lakshmaiah Education Foundation, Guntur, India, in 2015 and pursuing full time Ph.D in Electrical and Electronics Engineering at Koneru Lakshmaiah Education Foundation. His Current Research includes, Dynamic Modeling of Batteries for Renewable Energy Storage, Electric vehicles and Portable Electronics Applications, Renewable Energy Sources Integration with Battery Energy Storage Systems (BESS), Smart Metering and Smart Grids, Micro-Grids, AMR(Automatic Meter Reading) devices, GSM/GPRS and PLC (Power Line Carrier) Communication and Various modulation techniques such as QPSK, BPSK, ASK, FSK, OOK and GMSK.

Malligunta Kiran Kumar received B.Tech Degree in Electrical and Electronics Engineering from Gokula Krishna College of Engineering and Technology, JNTU, Hyderabad, India, in 2007, M.E. Degree in Power Electronics and Drives from Sree Sastha Institute of Engineering and Technology, Anna University, Chennai, India, in 2010 and Ph.D in Electrical Engineering at Koneru Lakshmaiah Education Foundation, Guntur, India, in 2016. His research interest includes Switched Reluctance Machines, Power Electronics and Control Systems. 